\title{
Assessment of probiotic-supplementation on growth performance, lipid peroxidation, antioxidant capacity, and cecal microflora in broiler chickens
}

\author{
Sahar F. Deraz ${ }^{1}$, Alaa E. Elkomy ${ }^{2}$, Ashraf A. Khali1 ${ }^{*}$ \\ ${ }^{1}$ Department of Protein Technology, Institute of Genetic Engineering and Biotechnology, City of Scientific Research and Technological Applications, \\ Alexandria, Egypt. \\ ${ }^{2}$ Department of Livestock Research, Arid Lands Cultivating Research Institute, City of Scientific Research and Technological Applications, Alexandria, Egypt.
}

\begin{tabular}{l}
\hline ARTICLE INFO \\
\hline Received on: 03/03/2018 \\
Accepted on: 29/03/2018 \\
Available online: 07/03/2019 \\
\\
\hline Key words: \\
Probiotic, Broiler chicken, \\
Salmonella, Lactic acid \\
bacteria, Cecal microflora.
\end{tabular}

\begin{abstract}
The aim of this work was to investigate the efficacy of a couple of probiotic lactic acid bacterial isolates, Lactococcus lactis ssp. lactis and Lactobacillus plantarum added separately or in combination to broiler diets. The experimental treatments received a basal diet with $22.4 \%$ protein and $3,160 \mathrm{kcal} / \mathrm{kg}$. Two hundred and ten 1-day-old Hubbard broilers were allocated in seven experimental groups as follows: Control group and six groups treated by both probiotic strains in drinking water with intended final concentration of $10^{9} \mathrm{cfu} / \mathrm{ml}$ and $/ \mathrm{or} 10^{12} \mathrm{cfu} / \mathrm{ml}$ separately or in combination for a period of 42 days and tested on scheduled intervals. Treatment effects on performance of broilers (organs weights) as well as certain serum constituents were determined. The composition of cecal microflora was also evaluated. Probiotic supplementation had no significant effect but some organs had relative weights slightly higher compared to control. However, the relative weight of the thyroid, spleen, and pancreas was significantly increased. Broilers that received both types of probiotic strains separately or in combination had significant decreases $(p<0.05)$ in both serum alanine aminotransaminase level and malondialdehyde along with a significant increase $(p<0.05)$ in total antioxidant capacity compared to control. The microbiological analysis indicated that the lactic acid bacterial population boosted predominantly. The total coliform and Salmonella counts were significantly reduced and/or totally eliminated in broiler groups supplemented with probiotics. In conclusion, this study showed that both probiotic lactic acid bacterial strains can be considered as a nutritional source for broiler chickens.
\end{abstract}

\section{INTRODUCTION}

The current world trend is to either eliminate or reduce the use of antibiotics in poultry feeds to avoid the appearance of antibiotic resistant bacterial populations with special concern of antibiotics used in human diseases treatments (Menten, 2001; Dale, 1992; Pelicano et al., 2003). According to the United States Department of Agriculture, feed-borne antibiotic growth

\footnotetext{
*Corresponding Author

Ashraf A. Khalil, Department of Protein Technology, Institute of

Genetic Engineering and Biotechnology, City of Scientific Research and Technological Applications, Alexandria, Egypt.

E-mail: ashraf_khalil@msn.com
}

This article was presented at the 5th Euro-Mediterranean Conference and Expoon Life Sciences, Pharma and Biomedicine (BioNat-V), Limassol, Cyprus. promoters have been fed $100 \%$ of the broilers and turkeys in the USA during the rearing period. In Brazil, with the exception of naturally grown, probably almost all broilers are given growth promoters as additives in ration (Menten, 2002). The great scrutiny on the use of antibiotic growth promoters by some scientists, consumers, activists, politicians, and bureaucrats in many countries has resulted in ban or severe restriction on the use of antibiotics as growth-promoting agents for poultry and starting a search for new and safer alternatives (Russell and Grimes, 2009; Menten, 2002). Recently, alternatives for substituting these traditional growth promoters have been evaluated and two alternatives proposed, among others, are prebiotics and probiotics (Rodriguez et al., 2012; Pelicano et al., 2003).

The first attempt at using living bacteria to replace antibiotics in poultry was by Tortuero (1973), and probiotic use 
has gained widespread interest since. Probiotics are live microflora that is fed to animals and beneficially affect the host animal by colonizing the intestinal environment and improving its microbial balance (Fuller, 1989). The probiotics have influencing enterocyte turnover, producing bacteriostatic compounds that limit the growth of pathogenic bacteria, and competing with pathogenic bacteria for binding sites and nutrients (Farthing, 2004). Besides, these microorganisms are responsible for production of metabolites such as vitamins of the B complex and digestive enzymes, stimulation of the immune system by influencing enterocyte turnover, detoxifying colonic contents, promoting lactose tolerance, and lowering serum cholesterol concentrations (Li et al., 2009; Salma et al., 2007; Willis et al., 2007; Walter et al., 2008).

The most common utilized probiotic strains in animals are including, lactic acid bacteria (LAB) (L. plantarum, L. bulgaricus, L. helveticus, L. acidophilus, L. lactis, L. casei, L. salivarius, and Bacillus subtilis), Enterococcus (E. faecium and E. faecalis), Bifidobacterium spp., yeast and fungi (Aspergillusoryzae and Saccharomyces cerevisiae) (Huang et al., 2004). So far, assortments of microbial species such as Lactobacillus, Bifidobacterium, Bacillus, Enterococcus, Streptococcus, and Saccharomyces have been used as probiotics in poultry (Owings et al., 1990; Jin et al., 1998; Ghadban, 2002; Kalavathy et al., 2003; Patterson and Burkholder, 2003; Gil De Los Santos et al., 2005). The ability of LAB to exclude foodborne pathogens such as Salmonella spp. has been intensively investigated with diverging degrees of prosperity (Patterson and Burkholder, 2003). When administered alone to commercial poults with idiopathic diarrhea, the LAB-based probiotics have been shown to exert a marginal beneficial effect on turkey performance that is comparable to that of antibiotics (Higgins et al., 2005).

Lactococcus lactis ssp. lactis (Lact. lactis) and Lactobacillus plantarum (L. plantarum) are among a wide variety of microbial species that have been isolated and fully characterized in our lab that showed significant activities against Salmonella enteric ATCC (American Type Culture Collection) 25566 and Yersinia enterocolitica ATCC 23715. Furthermore, our previous works demonstrated that these LAB isolates are probiotic candidates tolerated to simulated gastric juice, bile salt resistance, the hydrophobicity of the cell surface, resistance to low phenol concentration, autoaggregation, coaggregation, and reduction of cholesterol (Deraz, 2017; khalil et al., 2012).

The aim of this work was to evaluate the efficacy of both species probiotic Lact. lactis and L. plantarum separately or in combination on broiler nutrition along an experimental period of 42 days. Broiler performance, aspartate aminotransferase (AST) enzyme activity, malondialdehyde (MDA) content, and total antioxidant capacity (TAC) in serum were determined. Because chicken ceca are the most heavily populated gastrointestinal (GI) tract region (Mead, 2000), it was hypothesized that any beneficial dietary modulation of the intestinal environment should reflect in composition and activities of the cecal microflora. Therefore, certain cecal microflora at ages of 14, 28, and 42 days was also determined.

\section{MATERIALS AND METHODS}

\section{Bacterial strains}

Probiotic strains and bacteriocin-producing Lact. lactis and L. plantarum (Deraz, 2017; Khalil et al., 2012) were used for probiotic preparations. Stock cultures of both strains were stored at $-80^{\circ} \mathrm{C}$ in De Man, Regosa and Sharpe (MRS) medium containing $25 \%(\mathrm{v} / \mathrm{v})$ glycerol as a cryoprotectant. To produce fresh working cultures, strains were propagated twice in MRS at $37^{\circ} \mathrm{C}$ for $16-18$ hours before experimental use.

\section{Broiler chicks and husbandry}

Hubbard commercial broiler chicks were purchased from Poultry Research Center, Faculty of Agriculture, Alexandria University. The animal experiments were performed in accordance with the Guidelines for the Care and Use of Laboratory Animals of the National Institutes of Health.

The husbandry was conducted at the Poultry Research Center, Faculty of Agriculture, Alexandria University. Two hundreds and ten of 1-day age broiler chicks were randomly divided into seven groups, 30 chicks each. Chicks were caged in wire floor batteries under controlled environmental house along an experimental period of 42 days. Experimental diets were formulated to provide chicks with $22.4 \%$ protein and 3,160 kcal/ $\mathrm{kg}$. Feed and water were provided ad libitum. Fresh water was provided on a daily basis during the experiment period to all the pens to ensure the viability of the probiotic culture. Remaining water from the previous day was discarded before adding fresh water, including that from pens receiving the probiotic in drinking water. To reach the target application rate, expected water consumption was estimated based on the age of broilers receiving probiotic.

\section{Experimental design and probiotic treatments}

The randomly divided groups were treated as follows: The first group was provided diets and water ad libitum with no addition and considered as a control group. The remaining was supplemented with probiotic strains at various concentrations. Groups 2 and 3 (T1 and T2) were provided with Lact. lactis $\left(10^{9} \mathrm{cfu} / \mathrm{ml}\right.$ and $10^{12} \mathrm{cfu} / \mathrm{ml}$, respectively). Groups 4 and 5 (T3 and T4) were provided with L. plantarum $\left(10^{9} \mathrm{cfu} / \mathrm{ml}\right.$ and $10^{12}$ cfu/ml, respectively). Finally, groups 6 and 7 (T5 and T6) were provided with a combination of both probiotic strains at different concentrations. T5 received Lact. lactis $\left(10^{12} \mathrm{cfu} / \mathrm{ml}\right)$ plus $L$. plantarum $\left(10^{9} \mathrm{cfu} / \mathrm{ml}\right)$. T6 received Lact. lactis $\left(10^{9} \mathrm{cfu} / \mathrm{ml}\right)$ plus L. plantarum $\left(10^{12} \mathrm{cfu} / \mathrm{ml}\right)$. The intended LAB concentrations per $\mathrm{ml}$ drinking water were either $10^{9}$ or $10^{12} \mathrm{cfu}$ of each strain. To check for actual probiotic concentrations in water throughout the experimental period, 10-fold dilutions of drinking water samples were plated on MRS agar plates in duplicate then incubated overnight at $37^{\circ} \mathrm{C}$.

\section{Slaughtering and organ weighting}

Chicks were fasted over-night then individually weighted. Three broilers per treatment (T) at the age of 14, 28, and 42 days were slaughtered by severing the jugular vein. After scalding, feather picking, and evisceration carcass, organs (intestinal weight and length, pancreas, spleen, liver, kidney, fabrishia, thymus, thyroid gland, and adrenal gland) were weighted. Percentages of organs were calculated based on live body weights. Relative weight of each organ was calculated according to Almeida et al. (1979) as follows: Relative weight $=$ (organ weightlive body weight) $\times 100$ 


\section{Blood sampling}

While slaughtering, blood samples were collected from each treatment group into dry clean centrifuge tubes, blood samples, were then centrifuged for 15 minutes at 3,500 rpm to obtain serum, and stored at $-20^{\circ} \mathrm{C}$ for later analysis.

\section{Serum analysis}

Aspartate aminotransferase (AST) enzyme activity measured according to the method of Reitman and Frankel (1957). The MDA content, a measure of lipid peroxidation, was assayed in the form of thiobarbituric acid reactive substances (TBARS) by the method of Wills (1965). TAC was assayed by the method described by Koracevic et al. (2001). Serum calcium (Ca) and phosphorus $(\mathrm{P})$ concentration as $(\mathrm{mg} / \mathrm{dl})$ were measured according to the method of Tietz (1986) and ammonium molybdate methods by Gomorri (1942), respectively.

\section{Cecal microflora}

The carcasses were subsequently opened and the entire intestinal tract was removed aseptically. The tract was then divided into sections that were ligated with light twine before separating the ceca from the small intestine and then stored in sterile bags at $-80^{\circ} \mathrm{C}$. For the bacterial enumeration, cecal digesta was thawed and aseptically emptied in a new sterile bag. Immediately cecal digesta was diluted to 10 -fold (i.e., $10 \% \mathrm{w} / \mathrm{v}$ ) with sterile icecold anoxic phosphate-buffered saline (PBS) (0.1 M; pH 7.0) and subsequently homogenized for 3 minutes in a stomacher. Each cecal homogenate was serially diluted from $10^{-1}$ to $10^{-7}$. Dilutions were subsequently plated in duplicate on selective agar media for target bacterial groups and the enumeration results were expressed as colony-forming units (cfu) log 10 per ml. In particular, total viable count using plate count agar, MRS agar for LAB, MacConkey agar media for coliforms, Salmonella \& Shigella agar plates for Salmonella counts were used. Plates were then incubated at $37^{\circ} \mathrm{C}$ for 24 to 72 hours.

\section{Statistical analysis}

Data were analyzed by analysis of variance using the general linear model procedure (Statistical Analysis System (SAS), 2001). Differences among means were determined using Duncan test (Duncan, 1955).

\section{RESULTS AND DISCUSSION}

\section{Effect of probiotic supplementation on relative organ weights}

One of the widespread methods used for immune status evaluation in chicken is the measurement of immune organ weight (Heckert et al., 2002). Such relative organs comprise liver, spleen, bursa of fabricius, and thymus. For optimal Ig synthesis, adequate expansion of these organs is crucial (Glick, 1977). All birds were in sound health during the experimental period of 42 days. The slaughtered birds were randomly selected from a straightrun broiler chick group. In all cases, each value represents an average of three readings. The effects of addition of Lact. lactis and L. plantarum, alone or in combination, on relative weights of various organs are shown in Table 1. Supplementation with probiotics resulted in numerically high improvements compared to control group. Relative weights of the major digestive and immune organs of broilers after 42 days of experimental period were not statistically significantly affected by types or doses of both probiotic strains tested. Although the intestinal length of broilers at 42 days was insignificantly influenced $(p<0.05)$ by type or doses of probiotic strains used, addition of probiotics at concentration of $10^{12} \mathrm{cfu} / \mathrm{ml}$ (T2 and T4) highly improved the intestinal length. Lact. lactis at concentration of $10^{12} \mathrm{cfu} / \mathrm{ml}$ (T2) showed the longest intestine $(52.51 \mathrm{~cm})$, followed by L. plantarum at the same concentration (T4) with the intestinal length of 47.78 $\mathrm{cm}$. These results are in agreement with Denli et al. (2003) who reported that probiotics did not influence significantly $(p>0.05)$ the intestinal length of broilers after 42 days and suggested that refinement of feed efficacy, enhancing nutrient availability, and increasing of the feed digestion and absorption caused by probiotic containing treatments led to shorter intestine length.

In our experiments, the probiotics did not affect the relative weights of intestinal tracts of broilers after 42 days. Similar results were observed by Jin et al. (1998), Huang et al. (2004), and Olnood et al. (2015) who demonstrated that the probiotic supplement Lactobacillus, Lactobacillus johnsonii, L. casei or L. acidophilus did not have an effect on organ weights and intestinal weight. Interestingly, the treated groups received the probiotic preparations either individually or combined and had relatively higher intestine weights compared to control group (Table 1), suggesting that mode of action of probiotic strains would be alike.

On the other hand, probiotic supplementation significantly increased the relative weights of thyroid, spleen, and pancreas. These results totally coincided with the observations of Hatab et al. (2016) who reported that the thymus and spleen relative weight were significantly increased in the probiotic-fed broilers as compared to the control. The increase in the relative weight of spleen is also in agreement with the findings of Willis et al. (2007) who found that feeding broilers on probiotic caused increases in the relative weights of the spleen in the treated group. The increase in the relative weight of pancreas was also in agreement with the findings of Olnood et al. (2015) who found that feeding broilers on probiotic caused increases in the relative weights of the pancreas of the treatment group. Subsequently, valuable effects of Lact. lactis and L. plantarum supplementation in the gastrointestinal tract could result in amelioration of immune response leading to improvement of overall health and performance of chicks.

\section{AST activity, MDA content, and total antioxidant capacity (TAC)}

Table 2, 3 and 4 show values of serum aspartate aminotransaminase (AST) level level (U/l), lipid peroxidation determinedas the concentration of MDA $\mathrm{mg} / \mathrm{dl}$, and TAC (mmol/l) of tested broilers aged 14, 28, and 42 days.

AST activity has been known as precise serological indicators in the deterioration of the hepatic tissues (AbdelWahhab and Aly, 2005). We found out that serum AST levels decreased significantly $(p<0.05)$ in all experimental groups treated with probiotic strains when compared to control (Table $2)$. Furthermore, there were significant differences $(p<0.05)$ in serum AST level of experimental groups treated with probiotics. AST primarily situated in the cytoplasm and sent out into the blood system only when hepatic structural integrity is influenced 
Table 1. Values of internal organs $(X \pm \mathrm{SE}) *$ of broiler chickens given Lact. lactis and L. plantarum alone (Treatments 1, 2, 3, and 4) or in combination (Treatments 5 and 6) after 42 days.

\begin{tabular}{|c|c|c|c|c|c|c|c|c|}
\hline \multirow{2}{*}{ Organs } & \multicolumn{7}{|c|}{ Treatments*** } & \multirow{2}{*}{$p$ value } \\
\hline & Control & T1 & $\mathbf{T} 2$ & T3 & T4 & T5 & T6 & \\
\hline Gizzard & $3.10 \pm 0.09$ & $3.25 \pm 0.31$ & $3.46 \pm 0.18$ & $3.25 \pm 0.27$ & $3.70 \pm 3.32$ & $3.01 \pm 0.20$ & $3.08 \pm 0.39$ & 0.572 \\
\hline Somatic & $0.83 \pm 0.06$ & $0.75 \pm 0.02$ & $0.91 \pm 0.09$ & $0.77 \pm 0.05$ & $0.79 \pm 0.12$ & $0.75 \pm 0.05$ & $0.79 \pm 0.02$ & 0.625 \\
\hline Intestinal weight & $9.39 \pm 1.98^{\mathrm{Ns}}$ & $11.37 \pm 1.28^{\mathrm{Ns}}$ & $14.33 \pm 2.19^{\mathrm{Ns}}$ & $11.31 \pm 0.85^{\mathrm{Ns}}$ & $9.73 \pm 1.49^{\mathrm{Ns}}$ & $10.99 \pm 0.79^{\mathrm{Ns}}$ & $11.27 \pm 1.26^{\mathrm{Ns}}$ & 0.384 \\
\hline Intestinal length & $39.92 \pm 4.06^{\mathrm{Ns}}$ & $43.57 \pm 1.08^{\mathrm{Ns}}$ & $52.51 \pm 8.57^{\mathrm{Ns}}$ & $43.30 \pm 7.48^{\mathrm{Ns}}$ & $47.78 \pm 5.86^{\mathrm{Ns}}$ & $42.84 \pm 0.77^{\mathrm{Ns}}$ & $44.65 \pm 4.02^{\mathrm{Ns}}$ & 0.736 \\
\hline Thyroid & $0.015 \pm 0.001^{\mathrm{b}}$ & $0.025 \pm 0.007^{\mathrm{ab}}$ & $0.023 \pm 0.002^{\mathrm{ab}}$ & $0.022 \pm 0.002^{\mathrm{ab}}$ & $0.019 \pm 0.003^{\mathrm{b}}$ & $0.024 \pm 0.003^{\mathrm{ab}}$ & $0.036 \pm 0.008^{\mathrm{a}}$ & 0.131 \\
\hline Adrenal & $0.026 \pm 0.006^{\mathrm{Ns}}$ & $0.023 \pm 0.004^{\mathrm{Ns}}$ & $0.027 \pm 0.003^{\mathrm{Ns}}$ & $0.015 \pm 0.000^{\mathrm{Ns}}$ & $0.024 \pm 0.006^{\mathrm{Ns}}$ & $0.019 \pm 0.001^{\mathrm{Ns}}$ & $0.020 \pm 0.003^{\mathrm{Ns}}$ & 0.332 \\
\hline Kidney & $0.94 \pm 0.02^{\mathrm{Ns}}$ & $1.09 \pm 0.09^{\mathrm{Ns}}$ & $1.06 \pm 0.05^{\mathrm{Ns}}$ & $0.96 \pm 0.01^{\mathrm{Ns}}$ & $1.11 \pm 0.44^{\mathrm{Ns}}$ & $1.01 \pm 0.04^{\mathrm{Ns}}$ & $0.99 \pm 0.13^{\mathrm{Ns}}$ & 0.988 \\
\hline Thymus & $0.29 \pm 0.07^{\mathrm{Ns}}$ & $0.39 \pm 0.04^{\mathrm{Ns}}$ & $0.39 \pm 0.09^{\mathrm{Ns}}$ & $0.36 \pm 0.10^{\mathrm{Ns}}$ & $0.35 \pm 0.03^{\mathrm{Ns}}$ & $0.40 \pm 0.06^{\mathrm{Ns}}$ & $0.42 \pm 0.03^{\mathrm{Ns}}$ & 0.834 \\
\hline Fabrishia & $0.16 \pm 0.04^{\mathrm{Ns}}$ & $0.18 \pm 0.02^{\mathrm{Ns}}$ & $0.17 \pm 0.01^{\mathrm{Ns}}$ & $0.24 \pm 0.05^{\mathrm{Ns}}$ & $0.16 \pm 0.04^{\mathrm{Ns}}$ & $0.19 \pm 0.04^{\mathrm{Ns}}$ & $0.21 \pm 0.02^{\mathrm{Ns}}$ & 0.598 \\
\hline Liver & $3.46 \pm 0.06^{\mathrm{Ns}}$ & $4.35 \pm 0.76^{\mathrm{Ns}}$ & $3.62 \pm 0.03^{\mathrm{Ns}}$ & $3.72 \pm 0.21^{\mathrm{Ns}}$ & $5.91 \pm 1.76^{\mathrm{Ns}}$ & $3.65 \pm 0.18^{\mathrm{Ns}}$ & $3.82 \pm 0.12^{\mathrm{Ns}}$ & 0.296 \\
\hline Spleen & $0.08 \pm 0.00^{\mathrm{b}}$ & $0.10 \pm 0.02^{\mathrm{ab}}$ & $0.11 \pm 0.02^{\mathrm{ab}}$ & $0.11 \pm 0.01^{\mathrm{ab}}$ & $0.16 \pm 0.02^{\mathrm{a}}$ & $0.10 \pm 0.01^{\mathrm{ab}}$ & $0.11 \pm 0.02^{\mathrm{ab}}$ & 0.180 \\
\hline Pancreas & $0.43 \pm 0.02^{\mathrm{c}}$ & $0.55 \pm 0.03^{\mathrm{abc}}$ & $0.47 \pm 0.04^{\mathrm{bc}}$ & $0.63 \pm 0.01^{\mathrm{a}}$ & $0.50 \pm 0.07^{\mathrm{abc}}$ & $0.50 \pm 0.02^{\mathrm{abc}}$ & $0.59 \pm 0.05^{\mathrm{ab}}$ & 0.035 \\
\hline Heart & $0.64 \pm 0.02$ & $0.74 \pm 0.07$ & $0.68 \pm 0.06$ & $0.65 \pm 0.03$ & $0.75 \pm 0.09$ & $0.62 \pm 0.03$ & $0.70 \pm 0.06$ & 0.630 \\
\hline
\end{tabular}

abcdMeans with different superscripts are significantly different $(p<0.05) . *$ Each value represents the mean for three replicates.

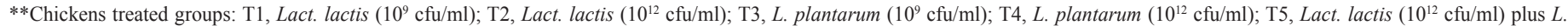
plantarum $\left(10^{9} \mathrm{cfu} / \mathrm{ml}\right)$; and $\mathrm{T} 6$, Lact. lactis $\left(10^{9} \mathrm{cfu} / \mathrm{ml}\right)$ plus L. plantarum $\left(10^{12} \mathrm{cfu} / \mathrm{ml}\right)$.

Table 2. Values $(X \pm \mathrm{SE}) *$ of AST liver enzyme in serum (U/1) of broiler chickens given Lact. lactis and L. plantarum alone (Treatments 1, 2, 3, and 4) or in combination (Treatments 5 and 6).

\begin{tabular}{|c|c|c|c|c|c|c|c|c|}
\hline \multirow{2}{*}{ Period } & \multicolumn{7}{|c|}{ Treatments** } & \multirow{2}{*}{$p$ value } \\
\hline & Control & T1 & T2 & T3 & T4 & T5 & T6 & \\
\hline 14 days & $171.34 \pm 10.5^{\mathrm{a}}$ & $141.5 \pm 3.1^{b}$ & $133.4 \pm 2.9^{\mathrm{bc}}$ & $131.7 \pm 2.7^{\mathrm{bc}}$ & $111.5 \pm 8.9^{\mathrm{cd}}$ & $134.1 \pm 14.1^{\mathrm{bc}}$ & $99.0 \pm 5.1^{\mathrm{d}}$ & 0.001 \\
\hline 28 days & $161.1 \pm 11.3^{\mathrm{a}}$ & $105.4 \pm 6.7^{\mathrm{cd}}$ & $127.3 \pm 10.2^{\mathrm{ab}}$ & $114.8 \pm 6.0^{\mathrm{c}}$ & $111.7 \pm 12.0^{\mathrm{c}}$ & $78.2 \pm 14.0^{\mathrm{d}}$ & $120.8 \pm 0.9^{\mathrm{bc}}$ & 0.001 \\
\hline 42 days & $140.6 \pm 7.8^{\mathrm{ab}}$ & $129.0 \pm 14.2^{\mathrm{abc}}$ & $107.2 \pm 4.6^{\mathrm{c}}$ & $135.2 \pm 6.9^{\mathrm{abc}}$ & $115.0 \pm 10.8^{\mathrm{a}}$ & $146.2 \pm 10.1^{\mathrm{a}}$ & $113.6 \pm 7.6^{\mathrm{bc}}$ & 0.019 \\
\hline Overall means & $157.7 \pm 6.7^{\mathrm{a}}$ & $125.3 \pm 7.0^{\mathrm{b}}$ & $122.6 \pm 6.8^{b}$ & $127.2 \pm 4.2^{\mathrm{b}}$ & $112.7 \pm 9.5^{\mathrm{b}}$ & $119.48 \pm 12.2^{\mathrm{b}}$ & $111.1 \pm 4.2^{\mathrm{b}}$ & 0.005 \\
\hline
\end{tabular}

abcd Means with different superscripts are significantly different $(p<0.05)$. Each value represents the mean for three replicates.

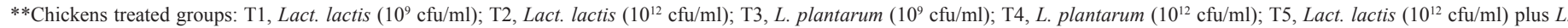
plantarum $\left(10^{9} \mathrm{cfu} / \mathrm{ml}\right)$; and $\mathrm{T} 6$, Lact. lactis $\left(10^{9} \mathrm{cfu} / \mathrm{ml}\right)$ plus L. plantarum $\left(10^{12} \mathrm{cfu} / \mathrm{ml}\right)$.

(Fan et al., 2015). Therefore, in our study, the increased serum AST activity observed in the control groups of chickens evidence that at least certain damage occurred in the liver and the decreased levels of AST may be associated with hepato-protective effects of the probiotic strains used. Among the six doses of applied probiotic treatments, T6 group, co-administration of Lact. lactis $\left(10^{9} \mathrm{cfu} / \mathrm{ml}\right)$ and L. plantarum $\left(10^{12} \mathrm{cfu} / \mathrm{ml}\right)$ showed the lowest AST activities (99.0, 120.8, and 113.6 U/1) along the whole experimental period followed by $\mathrm{T} 4$ which administered by L. plantarum at a final concentration of $10^{12} \mathrm{cfu} / \mathrm{ml}$ with AST activities of $111.5,111.7$, and $115.0(\mathrm{U} / 1)$ at 14, 28, and 42 days, respectively.

Our results were coincided with Santoso et al. (1995) who recorded that the probiotics had a lower level of AST. While Hussein (2014) reported that there were no effect on serum AST activities, after the addition of probiotic (Saccharomyces cerevisiae) as compared to control. However, in another study, addition of Saccharomyces cerevisiae caused significant increase in serum AST activity (Mannaa et al., 2005). The decrease in AST activity acquired in the current study harmonized comparable results of studies on rats provided with $B$. infantis and L. plantarum to which decreased AST activity (Osman et al., 2007). The variations in the enzymatic activities may be due to animal species and probiotic interferences (Aluwong et al., 2013). We proposed that decreased blood AST activities within the normal range in treated groups suggested normal status of liver function as a result of biological supplementation with L. plantarum and Lact. lactis.

TAC is the contrivance used to determine the level of free radicals scavenged in test sample (Ghiselli et al., 2000) which utilized to assess the antioxidant capacity of biological samples (Marques et al., 2014; Pinchuk et al., 2012; Bartosz, 2010). Free radicals could be produced in tissues and cells from outer sources (such as pollution, drugs, and food), internal (such as inflammation, diseases, or metabolism) or as a result of diminished protective capacity (Rice-Evans et al., 1991) and any excess in free radicals production can result in oxidative damage (Ghiselli et al., 2000; Rubio et al., 2016). Two known mechanisms have generated by organisms as an antioxidant defense system, one of them is based on the activity of antioxidant enzymes which neutralize free radicals and the other build on the subsistence of low-molecularweight antioxidants which directly interact with oxidant molecules leading to terminate the free radical chain reaction (Ognik et al., 2016, 2017).

MDA is the direct product of lipid peroxidation developed after radical attack on unsaturated fatty acids which can react with biomolecules and do cytotoxic, genotoxic effects and also could cause mutagenic lesions implicated in various diseases. Therefore, MDA content has an important role as an indicator of the lipid peroxidation level and as an indirect 
Table 3. Values $(X \pm \mathrm{SE}) *$ of MDA content (mg/dl) in the serum of broiler chickens given Lact. lactis and L. plantarum alone (Treatments 1,2 , 3, and 4) or in combination (Treatments 5 and 6).

\begin{tabular}{|c|c|c|c|c|c|c|c|c|}
\hline \multirow{2}{*}{ Period } & \multicolumn{7}{|c|}{ Treatments** } & \multirow{2}{*}{$p$ value } \\
\hline & Control & T1 & T2 & T3 & T4 & T5 & T6 & \\
\hline 14 days & $26.07 \pm 3.03^{b}$ & $18.60 \pm 0.96^{\mathrm{bc}}$ & $17.57 \pm 1.60^{\mathrm{bc}}$ & $11.20 \pm 0.64^{\mathrm{c}}$ & $21.30 \pm 1.67^{\mathrm{a}}$ & $19.67 \pm 2.22^{b c}$ & $14.37 \pm 5.74^{\mathrm{c}}$ & 0.001 \\
\hline 28 days & $19.27 \pm 2.96^{c}$ & $15.20 \pm 1.92^{\mathrm{ab}}$ & $7.70 \pm 0.69^{c}$ & $11.77 \pm 0.70^{\mathrm{bc}}$ & $8.47 \pm 0.59^{c}$ & $16.70 \pm 0.59^{\mathrm{a}}$ & $11.37 \pm 0.30^{\mathrm{bc}}$ & 0.002 \\
\hline 42 days & $48.50 \pm 2.66^{\mathrm{a}}$ & $8.83 \pm 0.49^{d}$ & $27.17 \pm 3.24^{\mathrm{b}}$ & $13.93 \pm 2.86^{\mathrm{cd}}$ & $11.30 \pm 0.50^{\mathrm{d}}$ & $19.50 \pm 1.76^{\mathrm{c}}$ & $14.57 \pm 2.75^{\mathrm{cd}}$ & 0.001 \\
\hline Overall means & $31.28 \pm 6.13$ & $14.21 \pm 1.57$ & $17.48 \pm 4.46$ & $12.30 \pm 0.96$ & $13.69 \pm 5.28$ & $18.62 \pm 0.96$ & $13.43 \pm 1.91$ & 0.068 \\
\hline
\end{tabular}

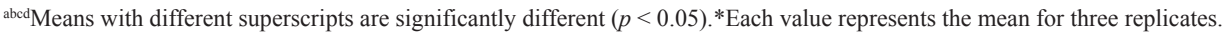

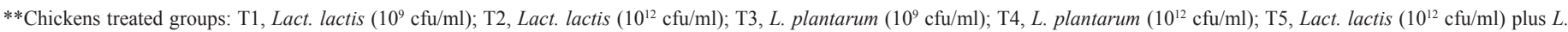
plantarum $\left(10^{9} \mathrm{cfu} / \mathrm{ml}\right)$; and $\mathrm{T} 6$, Lact. lactis $\left(10^{9} \mathrm{cfu} / \mathrm{ml}\right)$ plus L. plantarum $\left(10^{12} \mathrm{cfu} / \mathrm{ml}\right)$.

Table 4. Values $(X \pm \mathrm{SE})^{*}$ of TAC mmol/1 in the serum of broiler chickens given Lact. lactis and L. plantarum alone (Treatments $1,2,3$, and 4$)$ or in combination (Treatments 5 and 6).

\begin{tabular}{|c|c|c|c|c|c|c|c|c|}
\hline \multirow{2}{*}{ Period } & \multicolumn{7}{|c|}{ Treatments** } & \multirow{2}{*}{$p$ value } \\
\hline & Control & T1 & T2 & T3 & T4 & T5 & T6 & \\
\hline 14 days & $1.80 \pm 0.13^{\mathrm{bc}}$ & $2.04 \pm 0.13^{\mathrm{ab}}$ & $2.36 \pm 0.11^{\mathrm{a}}$ & $1.52 \pm 0.23^{\mathrm{c}}$ & $2.11 \pm 0.06^{\mathrm{ab}}$ & $2.11 \pm 0.03^{\mathrm{ab}}$ & $2.18 \pm 0.06^{\mathrm{ab}}$ & 0.006 \\
\hline 28 days & $1.95 \pm 0.09$ & $1.89 \pm 0.10$ & $2.26 \pm 0.09$ & $1.93 \pm 0.13$ & $2.12 \pm 0.10$ & $1.99 \pm 0.18$ & $2.05 \pm 0.06$ & 0.333 \\
\hline 42 days & $2.01 \pm 0.10$ & $2.28 \pm 0.11$ & $1.93 \pm 0.05$ & $2.20 \pm 0.18$ & $2.19 \pm 0.14$ & $2.28 \pm 0.08$ & $2.44 \pm 0.03$ & 0.071 \\
\hline Overall means & $1.92 \pm 0.06^{\mathrm{bc}}$ & $2.07 \pm 0.08^{\mathrm{abc}}$ & $2.18 \pm 0.08^{\mathrm{a}}$ & $1.88 \pm 0.13^{\mathrm{c}}$ & $2.14 \pm 0.05^{\mathrm{ab}}$ & $2.13 \pm 0.07^{\mathrm{abc}}$ & $2.22 \pm 0.06^{\mathrm{a}}$ & 0.031 \\
\hline
\end{tabular}

abcd Means with different superscripts are significantly different $(p<0.05)$. Each value represents the mean for three replicates.

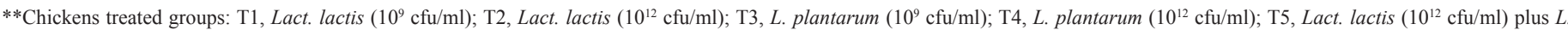
plantarum $\left(10^{9} \mathrm{cfu} / \mathrm{ml}\right)$; and T6, Lact. lactis $\left(10^{9} \mathrm{cfu} / \mathrm{ml}\right)$ plus L. plantarum $\left(10^{12} \mathrm{cfu} / \mathrm{ml}\right)$.

reflection of the extent of cell damage and aging in an organism (Spiteller, 2001; Puvača et al., 2015).

In our study, administration of probiotic preparations of Lact. lactis and/or L. plantarum at concentrations of $10^{9}$ or $10^{12} \mathrm{cfu} / \mathrm{ml}$ to chickens during their entire rearing period caused a significant reduction in MDA content and significant increase in TAC in blood serum compared to control groups (Tables 3 and 4). At 28 days old, probiotic-treated groups T2 (Lact. lactis, $10^{12} \mathrm{cfu} / \mathrm{ml}$ ) and $\mathrm{T} 4$ (L. plantarum, $\left.10^{12} \mathrm{cfu} / \mathrm{ml}\right)$ were recorded the lowest values of MDA contents of 7.70 and $8.47 \mathrm{mg} / \mathrm{dl}$, respectively. T3 (L. plantarum, $10^{9} \mathrm{cfu} / \mathrm{ml}$ ) and T6 (Lact. lactis, $10^{9} \mathrm{cfu} / \mathrm{ml}$ ) plus (L. plantarum, $10^{12} \mathrm{cfu} / \mathrm{ml}$ ) recorded MDA values of 11.77 and $11.37 \mathrm{mg} / \mathrm{dl}$, respectively in relationship to other treated groups (Table 3). However, at 42 days, the lowest MDA values were recorded with groups T1 (Lact. lactis, $10^{9} \mathrm{cfu} /$ $\mathrm{ml}$ ) followed by $\mathrm{T} 4$ (L. plantarum, $\left.10^{12} \mathrm{cfu} / \mathrm{ml}\right)$ with MDA values of 8.83 and $11.30 \mathrm{mg} / \mathrm{dl}$, respectively (Table 3). The significant reduction in MDA could be attributed to the probiotic ability to confer sufficient antioxidant protection against lipid peroxidation during the entire rearing period.

At 14 and 42 days of age, the levels of TAC were significantly increased $(p<0.05)$ in almost all treated groups in comparison to control. The more prominent significantly increase $(p<0.05)$ was in group T6 (Lact. lactis, $\left.10^{9} \mathrm{cfu} / \mathrm{ml}\right)$ plus $(L$. plantarum, $10^{12} \mathrm{cfu} / \mathrm{ml}$ ) at 42 days old (Table 4$)$. The current data coincide with the conclusion of Rajput et al. (2013) and Ognik and Krauze (2016) who stated that probiotics increase the activities of antioxidant enzymes including superoxide dismutase, catalase, and glutathione peroxidase and reduce the concentration of MDA and uric acid. Zheng et al. (2016) elucidate that the probiotic Enterococcus faecium bacteria promote resistance of biological macromolecules oxidation and take off hydroxyl radicals, herewith increasing the body's antioxidant capacity. Similar findings were also reported in broilers following probiotic administration by Rajput et al. (2013) and Shen et al. (2014) with supplementation of Saccharomyces boulardii, Bacillus subtilis, and L. plantarum, respectively.

Moreover, broilers receiving both types of probiotic strains separately or in combination had observed increase in serum calcium concentrations (Table 5). Calcium concentrations were obviously increased in almost all treated groups in comparison to control along the rearing period and the prominent increases were in group T2 (Lact. lactis, $10^{12} \mathrm{cfu} / \mathrm{ml}$ ) and T5 (Lact. Lactis, $10^{12} \mathrm{cfu} / \mathrm{ml}$ ) plus (L. plantarum, $10^{9} \mathrm{cfu} / \mathrm{ml}$ ) with mean values of 12.15 and $12.29 \mathrm{mg} / \mathrm{dl}$, respectively, compare to control with a mean value of $8.94 \mathrm{mg} / \mathrm{dl}$ (Table 5). However, the mean values of inorganic phosphorous concentrations were almost similar to control group except for groups T2 (Lact. lactis, $\left.10^{12} \mathrm{cfu} / \mathrm{ml}\right), \mathrm{T} 4$ (L. plantarum, $10^{12} \mathrm{cfu} / \mathrm{ml}$ ), and T6 (Lact. lactis, $10^{9} \mathrm{cfu} / \mathrm{ml}$ ) plus (L. plantarum, $10^{12} \mathrm{cfu} / \mathrm{ml}$ ) with values of $11.64,11.46$, and 11.85 $\mathrm{mg} / \mathrm{dl}$, respectively, compared to control with a mean value of $12.33 \mathrm{mg} / \mathrm{dl}$ (Table 6).

The observed increase in serum calcium and slight decrease in inorganic phosphorous concentrations in the treated groups as compared to the control group are in coincidence with the findings of Strompfova et al. (2006) who recorded a significant raise in serum calcium level of treated groups with E. faecium. However, the results were in contrast with the results obtained by Hashemzadeh et al. (2013) who stated no significant influence of probiotic on serum calcium and phosphorous levels in broiler chicks. Gilman and Gashman (2006) and Scholz et al. (2007) accounted that probiotics can promote the calcium absorption from intestinal tract. Furthermore, effectuation of probiotics resulted in beneficial influences of added probiotic on the damaged egg ratio through increased calcium retention in layers (Nahashon et al., 1996). 
Table 5. Values of $(X \pm \mathrm{SE}) *$ of calcium concentrations $(\mathrm{mg} / \mathrm{dl})$ in of broiler chickens given Lact. lactis and L. plantarum alone (Treatments 1, 2, 3, and 4) or in combination (Treatments 5 and 6).

\begin{tabular}{|c|c|c|c|c|c|c|c|c|}
\hline \multirow{2}{*}{ Period } & \multicolumn{7}{|c|}{ Treatments** } & \multirow{2}{*}{$p$ value } \\
\hline & Control & T1 & $\mathbf{T 2}$ & T3 & T4 & T5 & T6 & \\
\hline 14 days & $9.02 \pm 0.60$ & $11.50 \pm 0.36$ & $11.05 \pm 0.55$ & $11.62 \pm 0.59$ & $12.12 \pm 1.44$ & $11.76 \pm 0.57$ & $12.15 \pm 0.02$ & 0.921 \\
\hline 28 days & $9.20 \pm 0.91$ & $10.84 \pm 0.77$ & $12.91 \pm 0.88$ & $11.39 \pm 0.07$ & $11.24 \pm 0.78$ & $12.27 \pm 1.14$ & $11.25 \pm 0.17$ & 0.548 \\
\hline 42 days & $8.6 \pm 0.91$ & $12.31 \pm 0.50$ & $12.50 \pm 0.80$ & $10.79 \pm 1.22$ & $11.64 \pm 0.88$ & $12.85 \pm 1.32$ & $10.84 \pm 0.83$ & 0.658 \\
\hline Overall means & $8.94 \pm 0.61$ & $11.55 \pm 0.36$ & $12.15 \pm 0.47$ & $11.27 \pm 0.41$ & $11.67 \pm 0.55$ & $12.29 \pm 0.55$ & $11.41 \pm 0.31$ & 0.630 \\
\hline
\end{tabular}

*Each value represents the mean for three replicates.

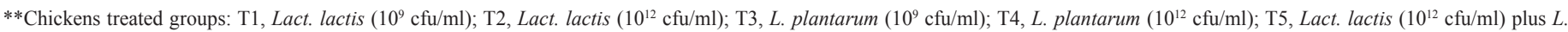
plantarum $\left(10^{9} \mathrm{cfu} / \mathrm{ml}\right)$; and T6, Lact. lactis $\left(10^{9} \mathrm{cfu} / \mathrm{ml}\right)$ plus L. plantarum $\left(10^{12} \mathrm{cfu} / \mathrm{ml}\right)$.

Table 6. Values $(X \pm \mathrm{SE}) *$ of phosphor concentrations $(\mathrm{mg} / \mathrm{dl})$ of broiler chickens given Lact. lactis and L. plantarum alone (Treatments 1,2 , 3, and 4) or in combination (Treatments 5 and 6).

\begin{tabular}{|c|c|c|c|c|c|c|c|c|}
\hline \multirow{2}{*}{ Period } & \multicolumn{7}{|c|}{ Treatments** } & \multirow{2}{*}{$P$ Value } \\
\hline & Control & T1 & $\mathbf{T} 2$ & T3 & T4 & T5 & T6 & \\
\hline 14 days & $12.84 \pm 1.45$ & $9.98 \pm 2.24$ & $11.30 \pm 1.14$ & $12.92 \pm 1.03$ & $12.09 \pm 0.16$ & $13.09 \pm 0.47$ & $11.41 \pm 1.08$ & 0.408 \\
\hline 28 days & $12.41 \pm 1.74$ & $15.05 \pm 3.55$ & $12.98 \pm 0.73$ & $13.80 \pm 1.21$ & $9.85 \pm 1.64$ & $12.52 \pm 0.78$ & $12.25 \pm 0.25$ & 0.556 \\
\hline 42 days & $11.74 \pm 2.36$ & $11.61 \pm 0.75$ & $10.64 \pm 1.68$ & $11.69 \pm 2.65$ & $12.43 \pm 0.78$ & $11.53 \pm 1.17$ & $11.87 \pm 1.98$ & 0.996 \\
\hline Overall means & $12.33 \pm 1.0$ & $12.21 \pm 1.44$ & $11.64 \pm 0.71$ & $12.80 \pm 0.94$ & $11.46 \pm 0.66$ & $12.38 \pm 0.49$ & $11.85 \pm 0.67$ & 0.918 \\
\hline
\end{tabular}

*Each value represents the mean for three replicates.

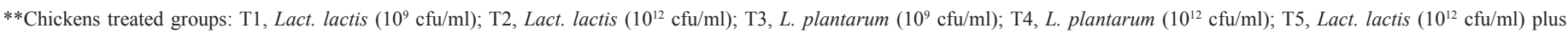
L. plantarum $\left(10^{9} \mathrm{cfu} / \mathrm{ml}\right)$; and T6, Lact. lactis $\left(10^{9} \mathrm{cfu} / \mathrm{ml}\right)$ plus L. plantarum $\left(10^{12} \mathrm{cfu} / \mathrm{ml}\right)$.

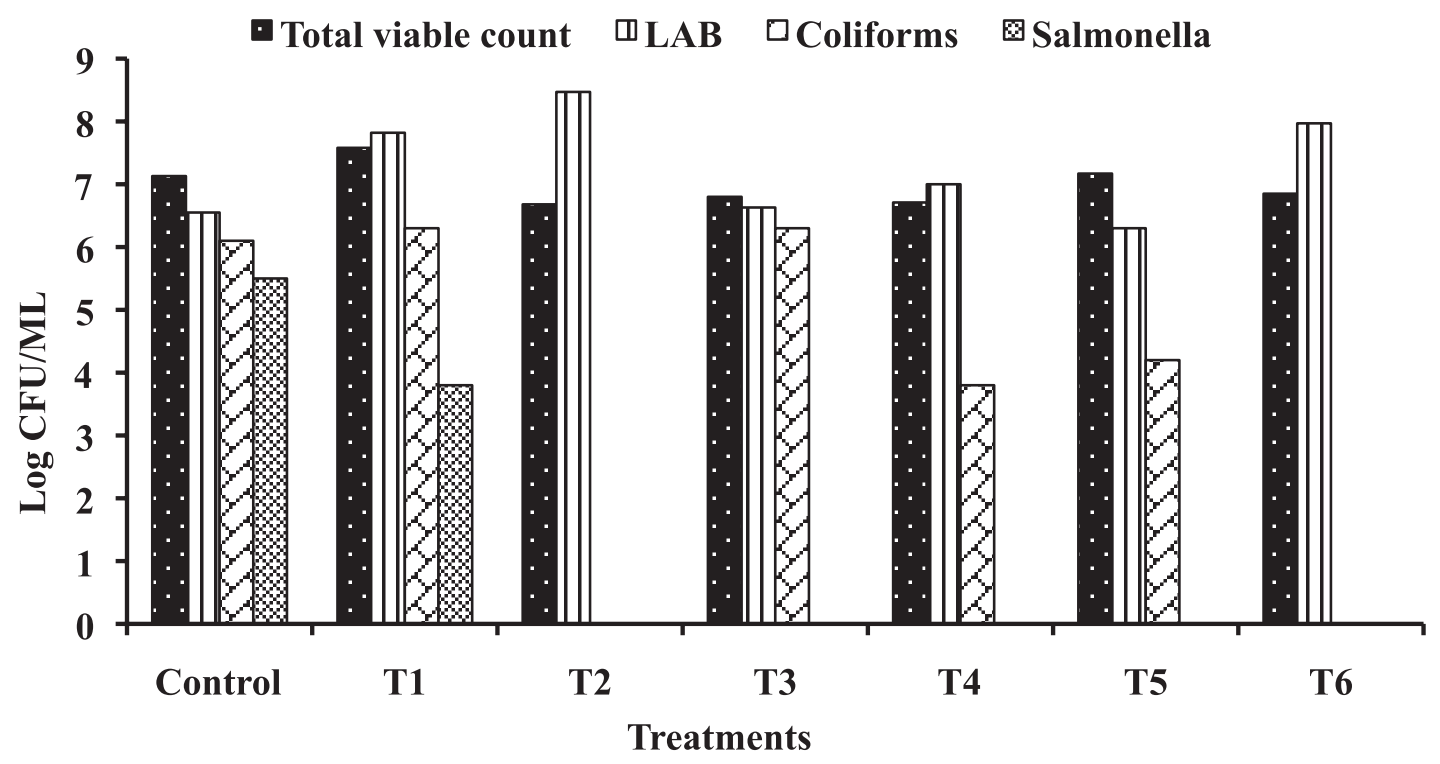

Figure 1. Cecal microflora composition of broiler chickens at the age of 14 days old given probiotic strains. Each bar represents the mean for three birds per treatment. Chickens treated groups: T1, Lact. lactis $\left(10^{9} \mathrm{cfu} / \mathrm{ml}\right)$; T2, Lact. lactis $\left(10^{12} \mathrm{cfu} / \mathrm{ml}\right)$; T3, L. plantarum $\left(10^{9} \mathrm{cfu} / \mathrm{ml}\right)$; T4, L. plantarum $\left(10^{12} \mathrm{cfu} / \mathrm{ml}\right) ; \mathrm{T} 5$, Lact. lactis $\left(10^{12} \mathrm{cfu} / \mathrm{ml}\right)$ plus L. plantarum $\left(10^{9} \mathrm{cfu} / \mathrm{ml}\right) ;$ and T6, Lact. lactis $\left(10^{9} \mathrm{cfu} / \mathrm{ml}\right)$ plus L. plantarum $\left(10^{12} \mathrm{cfu} / \mathrm{ml}\right)$.

\section{Cecal microflora composition}

Figure 1, 2 and 3 show effect of Lact. lactis and $L$. plantarum either separately or combined at different inclusion levels on the composition of cecal microflora at 14, 28, and 42 days of age. The represented data revealed that the total viable bacterial count, total coliform counts, and Salmonella counts were significantly reduced in some broilers groups supplemented with probiotics as compared to control depending on probiotic concentrations and/or sampling periods. However, it was also noted an increase in total viable bacterial count in birds supplemented with Lact. lactis at level of $10^{9} \mathrm{cfu} /$ $\mathrm{ml}$ compared to control group. The obtained results of the microbiological analysis indicated that the lactic acid bacterial population boosted predominantly and were the most numerous 


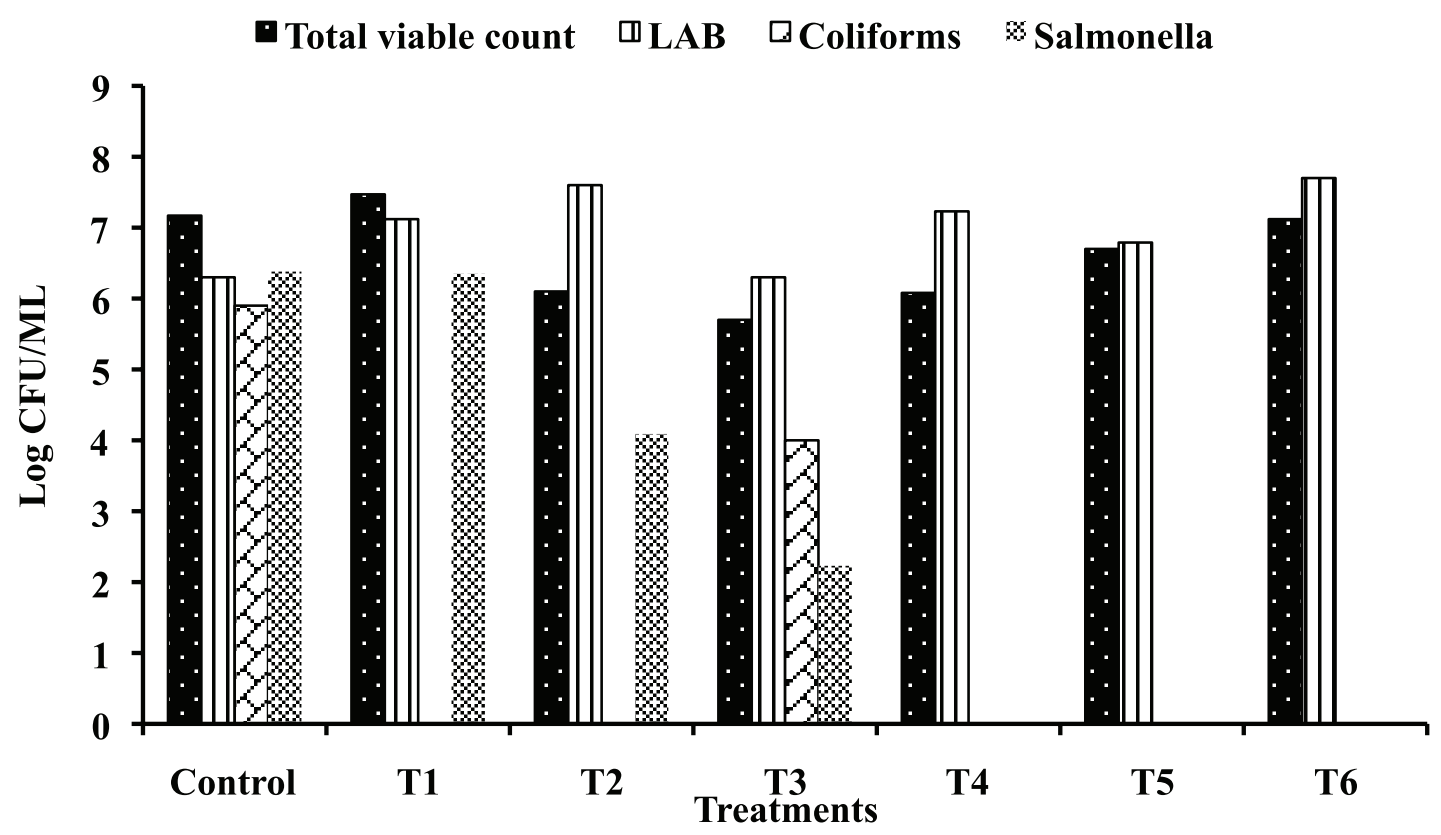

Figure 2. Cecal microflora composition of broiler chickens at the age of 28 days old given probiotic strains. Each bar represents the mean for three birds per treatment. Chickens treated groups: T1, Lact. lactis $\left(10^{9} \mathrm{cfu} / \mathrm{ml}\right) ; \mathrm{T} 2$, Lact. lactis $\left(10^{12} \mathrm{cfu} / \mathrm{ml}\right) ; \mathrm{T} 3, L$. plantarum $\left(10^{9} \mathrm{cfu} / \mathrm{ml}\right) ; \mathrm{T} 4$, L. plantarum $\left(10^{12} \mathrm{cfu} / \mathrm{ml}\right) ; \mathrm{T} 5$, Lact. lactis $\left(10^{12} \mathrm{cfu} / \mathrm{ml}\right)$ plus L. plantarum $\left(10^{9} \mathrm{cfu} / \mathrm{ml}\right)$; and T6, Lact. lactis $\left(10^{9} \mathrm{cfu} / \mathrm{ml}\right)$ plus L. plantarum $\left(10^{12} \mathrm{cfu} / \mathrm{ml}\right)$.

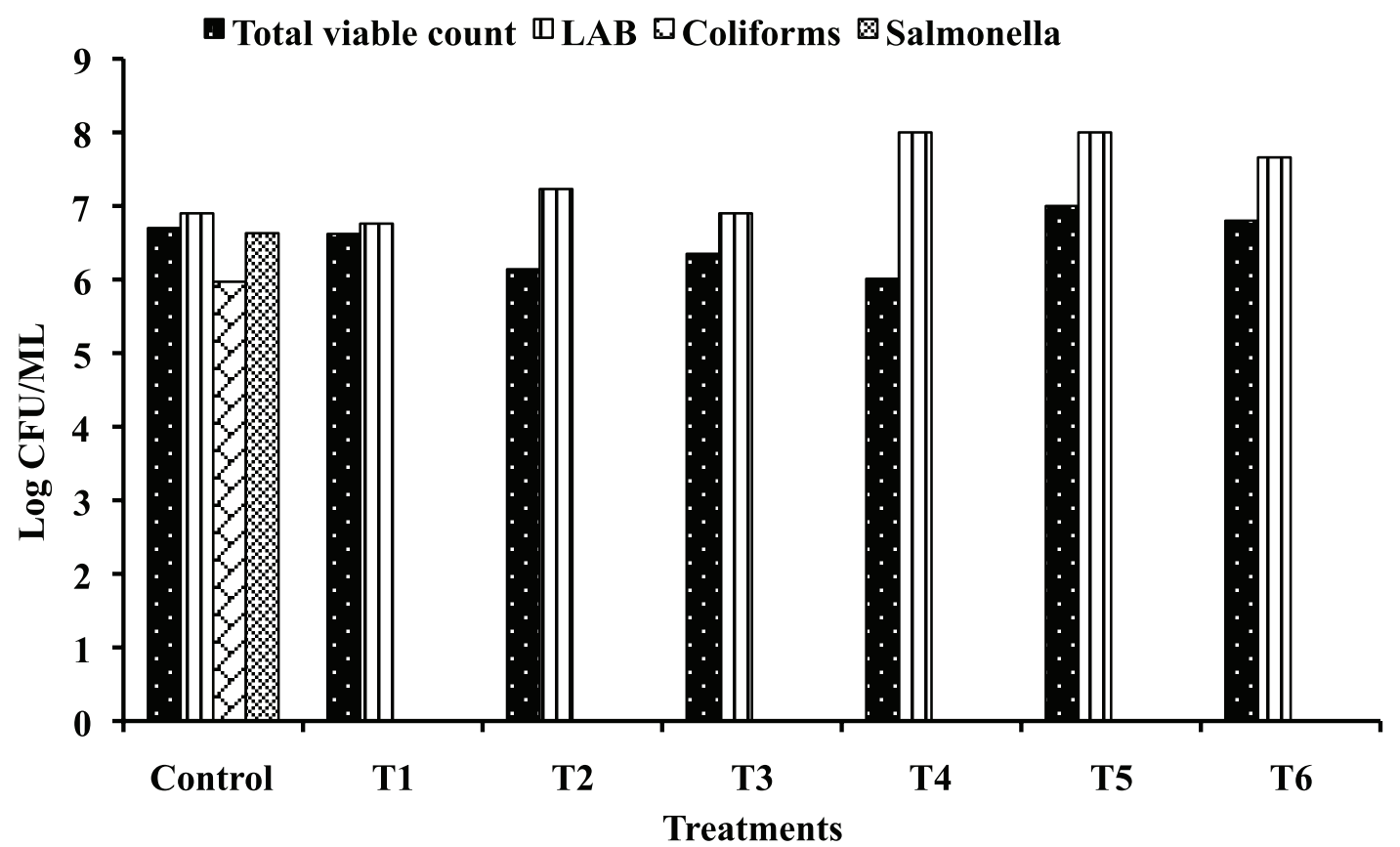

Figure 3. Cecal microflora composition of broiler chickens at the age of 42 days old given probiotic strains. Each bar represents the mean for three birds per treatment. Chickens treated groups: T1, Lact. lactis $\left(10^{9} \mathrm{cfu} / \mathrm{ml}\right) ; \mathrm{T} 2$, Lact. lactis $\left(10^{12} \mathrm{cfu} / \mathrm{ml}\right) ; \mathrm{T} 3$, L. plantarum $\left(10^{9} \mathrm{cfu} / \mathrm{ml}\right) ; \mathrm{T} 4$, L. plantarum $\left(10^{12} \mathrm{cfu} / \mathrm{ml}\right) ; \mathrm{T} 5$, Lact. lactis $\left(10^{12} \mathrm{cfu} / \mathrm{ml}\right) \mathrm{plus}$ L. plantarum $\left(10^{9} \mathrm{cfu} / \mathrm{ml}\right) ;$ and $\mathrm{T} 6$, Lact. lactis $\left(10^{9} \mathrm{cfu} / \mathrm{ml}\right)$ plus L. plantarum $\left(10^{12} \mathrm{cfu} / \mathrm{ml}\right)$.

microorganisms present in the cecum of broiler chicks that consumed a basal diet with microbial supplement of Lact. lactis and L. plantarum either separately and/or in combinations using different inclusion levels in comparison with control group (Fig. 1,2 and 3). Lactic acid bacterial counts reached a maximum concentration in $\mathrm{T} 2$ group subjected to Lact. lactis $\left(10^{12} \mathrm{cfu} / \mathrm{ml}\right)$ and T6 (Lact. lactis, $10^{9} \mathrm{cfu} / \mathrm{ml}$ ) plus (L. plantarum, $10^{12} \mathrm{cfu} /$ $\mathrm{ml}$ ) after 14 days; afterwards these values declined but remained significantly high. These results are in agreement with those of Mountzouris et al. $(2007,2010)$ who reported that probiotics- 
supplemented diets of broilers gave higher Lactobacilli, Bifidobacterium, and gram-positive cocci concentrations of the cecal microflora compared to controls. These observations were also stated by other researchers (AbuTarboush et al., 1996; Jenny et al., 1991; Ellinger et al., 1980). In addition, considerable number of investigations confirmed that probiotic addition in broiler feed could regulate the intestinal microflora and enhance the beneficial bacteria concentration such as LAB, and at the same time, inhibit the proliferation of harmful bacteria (Line et al., 1998; Li et al., 2008). On the contrary, these results are in partial disagreement with those of Giannenas et al. (2012) and Pourakbari et al. (2016) who did not detect differences in Lactobacilli and Enterococci counts, in the cecum of broilers fed a probiotic supplemented diet compared to control.

Total coliform counts and Salmonella counts in the ceca were highly diminished or totally eliminated throughout the assay, with almost no variance of values within the individual treated groups. Variations observed only in counts of a couple of groups, namely, T1 (Lact. lactis, $10^{9} \mathrm{cfu} / \mathrm{ml}$ ) and $\mathrm{T} 3$ (L. plantarum, $10^{9} \mathrm{cfu} / \mathrm{ml}$ ) compared to control group (Fig. 1, 2 and 3 ). The proliferation of both total coliform counts and Salmonella was prevented in favor of LAB in almost all treatments compared to control. A similar potential of the particular probiotic to modulate the composition of cecal microflora and suppress potentially pathogenic bacteria such as coliforms and Salmonella was previously evidenced (Koenen et al., 2004; Teo and Tan, 2007; Higgins et al., 2008; Vicente et al., 2008; Mountzouris et al., 2010). Continual probiotic supplementation to animals feed has been found to enhance the proliferation of beneficial intestinal microflora in two routes, first by competitive insularity and second through antagonistic activity towards pathogenic bacteria (Jin et al.,1997; Riddell et al., 2010). In this way, probiotics can leverage the intestinal microbiota as well as host health, also increasing nutrient utilization, producing antimicrobial compounds, and stimulating the immune system (Corcionivoschi et al., 2010). The bactericidal effect of probiotic was probably due to production of different antimicrobial compounds by the probiotic strains such as antimicrobial peptides (bacteriocins), organic acids, diacetyl, hydrogen peroxide, and carbon peroxide. Some bacteriocins produced by specific probiotic strains can fulfill a role in the inhibition of common broiler pathogens (Ali, 2010). Both probiotic strains used in the current study, Lact. lactis and L. plantarum have a confirmed bacteriocin production activity against Salmonella enteric ATCC 25566, Yersinia enterocolitica ATCC 2371, and Bacillus cereus ATCC 49064 (Deraz, 2017; Khalil et al., 2012).

In conclusion, this study showed beneficial effects of dietary inclusion of both bacteriocins producing and probiotic strains Lact. lactis and L. plantarum and can be considered as a wealthy source of chicken nutritional supplement.

\section{REFERENCES}

Abdel-Wahhab MA, Aly SE. Antioxidant property of Nigella sativa (black cumin) and Syzygiumaromaticum (clove) in rats during aflatoxicosis. J Appl Toxicol, 2005; 25:218-23.

Abu-Tarboush HM, Al-Saiady MY, Keir El-Din AH. Evaluation of diet containing lactobacilli on performance, fecal coliform, and lactobacilli of young dairy calves. Anim Feed Sci Technol, 1996; 57:39-49.
Ali FHM. Probiotic fed supplement to improve quality of broiler chicken carcasses. World J Dairy Food Sci, 2010; 5:93-9.

Almeida HO, Teixeira VPA, Araújo WF. Comportamento do peso do coração e do corpoemchagásicoscrônicos com e sem "megas." Rev Soc Bras Med Trop, 1979; 13:85-9.

Aluwong T, Hassan FB, Raji MA, Kawu MU, Dzenda T, Ayo JO. Effect of different levels of supplemental yeast on performance indices, serum enzymes and electrolytes of broiler chickens. Afr J Biotechnol, 2013; 12:5480-5.

Bartosz G. Non-enzymatic antioxidant capacity assays: limitations of use in biomedicine. Free Radic Res, 2010; 44:711-20.

Corcionivoschi N, Drinceanu D, Pop I, Stack M, Stef D, Julean L. The effect of probiotics on animal health. J Anim Sci Biotechnol, 2010; 43:35-41.

Dale N. Probióticosparaaves. A Vicultura Profesional, 1992; $10: 88-9$.

Denli M, Okan F, Celik K. Effect of dietary probiotic, organic acid and antibiotic supplementation to diets on broiler performance and carcass yield. Pak J Nutr, 2003; 2:89-91.

Deraz SF. Production of natural cured fresh oriental sausage by meat-associated LAB with different nitrite- and nitrate-reductase activities: a potential solution for nitrite free and low nitrite meat products. Carpathian J Food Sci Tech, 2017; 9:23-39.

$1955 ; 11: 1-42$

Duncan DB. Multiple range and multiple F tests. Biometrics,

Ellinger DK, Muller LD, Glantz PJ. Influence of feeding fermented colostrum and Lactobacillus acidophilus on fecal flora of dairy calves. J Dairy Sci, 1980; 63:478-82.

Fan Y, Zhao L, Ji C, Li X, Jia R, Xi L, Zhang J, Ma Q. Protective effects of Bacillus subtilis ANSB060 on serum biochemistry, histopathological changes and antioxidant enzyme activities of broilers fed moldy peanut meal naturally contaminated with aflatoxins. Toxins, 2015; 7:3330-43.

Farthing MJG. Bugs and the gut: an unstable marriage. Best Prac Res Clin Gastroenterol, 2004; 18:233-9.

Fuller R. Probiotics in man and animals. A review. J Appl Bacteriol, 1989; 66:365-78.

Ghadban GS. Probiotics in broiler nutrition-a review. ArchivfürGeflügelkunde, 2002; 66:49-58.

Ghiselli A, Serafini M, Natella F, Scaccini C. Total antioxidant capacity as a tool to assess redox status: critical view and experimental data Free Radic Biol Med, 2000; 29:1106-14.

Giannenas I, Papadopoulos E, Tsalie E, Triantafillou EL, Henikl S, Teichmann K, Tontis D. Assessment of dietary supplementation with probiotics on performance, intestinal morphology and microflora of chickens infected with Eimeriatenella. Vet Parasitol, 2012; 188:31-40.

Gil De Los Santos JR, Storch OB, Gil-Turnes C. Bacillus cereus var. toyoii and Saccharomyces boulardii increased feed efficiency in broilers infected with Salmonella Enteritidis. Br Poult Sci, 2005; 46:494-7.

Gilman J, Cashman KD. The effect of probiotic bacteria on transepithelial calcium transport and calcium uptake in human intestinallike Caco-2 cells. Curr Issues Intest Microbiol, 2006; 7:1-5.

Glick B. The bursa of Fabricius and immunoglobulin synthesis. Int Rev Cytol, 1977; 48:345-402.

Gomorri G. Modification of the colorimetric phosphorus determination for use with the photoelectric colorimeter. J Lab Vin Med, 1942; 27:995

Hashemzadeh F, Shaban R, Mohammad A, Karimi T, Ali Akbar M. Effects of probiotics and antibiotic supplementation on serum biochemistry and intestinal microflora in broiler chicks. Int J Agri Crop Sci, $2013 ; 5: 2394-8$.

Hatab MH, Elsayed MA, Ibrahim NS. Effect of some biological supplementation on productive performance, physiological and immunological response of layer chicks. J Rad Res Appl Sci, 2016; 9:185-92. 
Heckert RA, Estevez I, Russek-Cohen E, Pettit RR. Effects of density and perch availability on the immune status of broilers. Poul Sci, 2002; 81:451-7.

Higgins SE, Higgins JP, Wolfenden AD, Henderson SN, TorresRodriguez A, Tellez G, Hargis B. Evaluation of a Lactobacillus-based probiotic culture for the reduction of Salmonella Enteritidis in neonatal broiler chicks. Poult Sci, 2008; 87:27-31.

Higgins SE, Torres-Rodriguez JL, Vicente CD, Sartor CM, Pixley GM, Nava G, Tellez G, Barton JT, Hargis BM. Evaluation of intervention strategies for idiopathic diarrhea in commercial turkey brooding houses. J Appl Poult Res, 2005; 14:345-8.

Huang MK, Choi YJ, Houde R, Lee JW, Lee B, Zhao X. Effects of lactobacilli and an acidophilic fungus on the production performance and immune responses in broiler chickens. Poult Sci, 2004; 83:788-95.

Hussein AF. Effect of biological additives on growth indices and physiological responses of weaned najdi ram lambs. J Experim Biol Agric Sci, 2014; 2:597-607.

Jenny BF, Vandkijk HJ, Collins JA. Performance and fecal flora of calves fed a Bacillus subtilis concentrate. J Dairy Sci, 1991; 74:1968-73.

Jin LZ, Ho YW, Abdullah N, Jalaludin S. Probiotics in poultry: modes of action. World's Poult Sci J, 1997; 53:351-68.

Jin LZ, Ho YW, Abdullah N, Jalaludin S. Growth performance, intestinal microbial populations, and serum cholesterol of broilers fed diets containing Lactobacillus cultures. Poult Sci 1998; 77:1259-65.

Kalavathy R, Abdullah N, Jalaludin S, Ho YW. Effects of Lactobacillus cultures on growth performance, abdominal fat deposition, serum lipids and weight of organs of broiler chickens. Br Poult Sci, 2003; 44:139-44.

Khalil AA, Shehata MG, El-Banna AA, Deraz SF, El-Sahn MA Probiotic potential of $L$. plantarum isolated from Zabady. Alex J Fd Sci Technol, 2012; 9:17-31.

Koenen, ME, Kramer J, Van Der Hulst R, Heres L, Jeurissen SHM, Boersma WJA. Immunomodulation by probiotic Lactobacilli in layer- and meat-type chickens. Br Poult Sci, 2004; 45:355-66.

Koracevic D, Koracevic G, Djordjevic V, Andrejevic S, Cosic V. Method for the measurement of antioxidant activity in human fluids. J Clin Pathol ,2001; 54:356-61.

Li SP, Zhao XJ, Wang JY. Synergy of Astragalus polysaccharides and probiotics (Lactobacillus and Bacillus cereus) on immunity and intestinal microbiota in chicks. Poult Sci, 2009; 88:519-25.

Li X, Qiang L, Liu, Xu CH. Effects of supplementation of fructooligosaccharide and/or Bacillus Subtilis to diets on performance and on intestinal microflora in broilers. Arch Tierz, 2008; 51:64-70.

Line EJ, Bailey SJ, Cox NA, Stern NJ, Tompkins T. Effect of yeast-supplemented feed on Salmonella and Campylobacter populations in broilers. Poult Sci, 1998; 77:405-10.

Mannaa F, Ahmed HH, Estefan SF, Sharaf HA, Eskander EF. Saccharomyces cerevisiae intervention for relieving flutamide induced hepatoxicity in male rats. Pharmazie, 2005; 60:689-95.

Marques SS, Magalhães LM, Tóth IV, Segundo MA. Insights on antioxidant assays for biological samples based on the reduction of copper complexes-the importance of analytical conditions. Int J Mol Sci, 2014; 15:11387-402.

Mead GC. Prospects for "competitive exclusion" treatment to control salmonellas and other foodborne pathogens in poultry. Vet J, 2000; 159:111-23.

Menten JFM. Aditivosalternativosnanutrição de aves: Probióticos e Prebióticos. Sociedade Brasileira de Zootecnia A produção animal navisão dos brasileiros, Fealq, Piracicaba, Brazil, pp 141-57, 2001.

Menten JFM. Probióticos, Prebióticos e Aditivos Fitogênicosna Nutrição de Aves. In: IIS impósiosobre Ingredientesna Alimentação Animal. CBNA, Brazil, pp 251-75, 2002.

Mountzouris KC, Tsitrsikos P, Palamidi I, Arvaniti A, Mohnl M, Schatzmayr G, Fegeros K. Effects of probiotic inclusion levels in broiler nutrition on growth performance, nutrient digestibility, plasma immunoglobulins, and cecal microflora composition. Poultry Sci, 2010; 89:58-67.
Mountzouris KC, Tstrsikos P, Kalamara E, Nitsch S, Schatzmayr G, Feceros K. Evaluation of the efficacy of a probiotic containing Lactobacillus, Bifidobacterium, Enterococcus, and Pediococcus strains in promoting broiler performance and modulating cecal microflora composition and metabolic activities. Poultry Sci, 2007; 86:309-17.

Nahashon SN, Nakaue HS, MIrosh LW. Performance of single comb White Leghorn layers fed a diet with a live microbial during the growth and egg laying phases. Anim Feed Sci Technol, 1996; 57:25-38.

Ognik K, Cholewinsk E, Sembratowicz I, Grela E, Czech A. The potential of using plant antioxidants to stimulate antioxidant mechanisms in poultry. Worlds Poult Sci J, 2016; 72:291-8.

Ognik K, Krauze M, Cholewińska E, Abramowicz K. The effect of a probiotic containing Enterococcus faecium DSM 7134 on redox and biochemical parameters in chicken blood. Ann Anim Sci, 2017; 17:1075-88,

Ognik K, Krauze M. The potential for using enzymatic assays to assess the health of turkeys. Worlds Poult Sci J, 2016; 72:535-50.

Olnood CG, Beski SSM, Iji PA, Choct M. Delivery routes for probiotics: effects on broiler performance, intestinal morphology and gut microflora. Anim Nut, 2015; 1:192-202.

Osman N, Adawi D, Ahme S, Jeppsson B, Molin C. Endotoxinand D-galactosamine- induced liver injury improved by the administration of Lactobacillus, Bifidobactrerium and blueberry. Digest Liver Dis, 2007; 39:849-56.

Owings WJ, Reynolds DL, Hasiak RJ, Ferket PR. Influence of a dietary supplementation with Streptococcus faecium M-74 on broiler body weight, feed conversion, carcass characteristics and intestinal microbial colonization. Poult Sci, 1990; 69:1257-64.

Patterson JA, Burkholder KM. Application of prebiotics and probiotics in poultry production. Poult Sci, 2003; 82:627-31.

Pelicano ERL, Souza PA, de Souza HBA, de Oba A, Norkus EA, Kodawara LM, De Lima TM. Effect of different probiotics on broiler carcass and meat quality. Braz J Poult Sci, 2003; 5:207-14.

Pinchuk I, Shoval H, Dotan Y, Lichtenberg D. Evaluation of antioxidants: scope, limitations and relevance of assays. Chem Phys Lipids, $2012 ; 165: 638-47$

Pourakbari M, Seidav A, Asadpour L, Martín A. Probiotic level effects on growth performance, carcass traits, blood parameters, cecal microbiota, and immune response of broilers. An Acad Bras Cienc, 2016; 9:1-16.

Puvaĉa N, Kostadinović LJ, Popović S, Lević J, Ljubojević D, Tufarelli V, Jovanović R, Tasić T, Ikonić P, Lukač D. Proximate composition, cholesterol concentration and lipid oxidation of meat from chickens fed dietary spice addition (Allium sativum, Piper nigrum, Capsicum annuum). Anim Prod Sci, 2015; 88.

Rajput IR, Li YL, Xu X, Huang Y, Zhi WC, Yu DY, Li W. Supplementary effects of Saccharomyces boulardii and Bacillus subtilis B10 on digestive enzyme activities, antioxidation capacity and blood homeostasis in broiler. IJABE, 2013; 15:231-7.

Reitman S, Frankel S. A colorimetric method for the determination of serum glutamic oxalacetic and glutamic pyruvic transaminases. Am J Clin Pathol, 1957; 28:56-63.

Rice-Evans CA, Diplock AT, Symons MC. Techniques in free radical research. Elsevier, London, UK, 1991.

Riddell JB, Gallegos AJ, Harmon DL, Mcleod KR. Addition of a bacillus based probitic to the diet of preruminant calves: influence on growth, health, and blood parameters. Int J Appl Res Vet Med, 2010; $8: 78-85$.

Rodriguez ML, Rebole A, Velasco S, Ortiz LT, Trevino J, Alzueta C. Wheat- and barley-based diets with or without additives influence broiler chicken performance, nutrient digestibility and intestinal microflora. J Sci Food Agric, 2012; 92:184-90.

Rubio CP, Hernández-Ruiz J, Martinez-Subiela S, Tvarijonaviciute A, Ceron JJ. Spectrophotometric assays for total antioxidant capacity (TAC) in dog serum: an update. BMC Vet Res, 2016; 12:166.

Russell SM, Grimes JL. The effect of a direct-fed microbial (Primalac) on turkey live performance. J Appl Poult Res, 2009; 18:185-92. 
Salma U, Miah AG, Maki T, Nishimura M, Tsujii H. Effect of dietary Rhodobactercapsulatus on cholesterol concentration and fatty acid composition in broiler meat. Poult Sci, 2007; 86:1920-6.

Santoso U, Tanaka K, Ohtania S. Effect of dried Bacillus subtilis culture on growth, body composition and hepatic lipogenic enzyme activity in female broiler chicks. Brit J Nutr, 1995; 74:523-9.

SAS. SAS/STAT software: changes and enhancements release 8.02. SAS Institute, Cary, NC, 2001.

Scholz AKE, Ade P, Marten B, Weber P, Timm W, Açil Y, Glüer CC, Schrezenmeir J. Prebiotics, probiotics, and synbiotics affect mineral absorption, bone mineral content, and bone structure. J Nutr, 2007; 137:838S-46S

Shen X, Yi D, Ni X, Zeng D, Jing B, Lei M, Bian Z, Zeng Y, Li T, Xin J. Effects of L. plantarum on production performance, immune characteristics, antioxidant status, and intestinal microflora of bursinimmunized broilers. Can J Microbiol, 2104; 60:193-202.

Spiteller G. Lipid peroxidation in aging and age-dependent diseases. Exp Gerontol, 2001; 36:1425-57.

Strompfova V, Marcinakov M, Simonov M, Gancarcikova S, Jonecova Z, Scirankov L, Koščová J, Buleca V, Čobanová K, Lauková A. Enterococcus faecium EK13-an enterocinaproducing strain with probiotic character and its effect in piglets. Anaerobe, 2006; 12:242-8.

Teo AY, Tan HM. Evaluation of the performance and intestinal gut microflora of broilers fed on corn-soy diets supplemented with Bacillus subtilis PB6 (CloSTAT). J Appl Poult Res, 2007; 16:296-303.

Tietz NW. Fundamentals of clinical chemistry. WB Saunders Company, Philadelphia, PA, p 723, 1986.

Tortuero F. Influence of implantation of Lactobacillus acidophilus in chicks on the growth, feed conversion, malabsorption of fats syndrome and intestinal flora. Poult Sci, 1973; 52:197-203.
Vicente JL, Torres-Rodriguez A, Higgins SE, Pixley C, Tellez G, Donoghue AM, Hargis BM. Effect of a selected Lactobacillus spp.-based probiotic on Salmonella entericaserovar Enteritidis-infected broiler chicks. Avian Dis, 2008; 52:143-6.

Walter J, Schwab C, Loach DM, Gänzle MG, Tannock GW. Glucosyltransferase A (GtfA) and inulosucrase (Inu) of Lactobacillus reuteri TMW1.106 contribute to cell aggregation, in vitro biofilm formation, and colonization of the mouse gastrointestinal tract. Microbiology, 2008, $154: 72-80$

Willis WL, Isikhuemhen OS, Ibrahim SA. Performance assessment of broiler chickens given mushroom extract alone or in combination with probiotics. Poult Sci, 2007; 86:1856-60.

Wills ED. Mechanisms of lipid peroxide formation in tissues. Role of metals and haematin proteins in the catalysis of the oxidation of unsaturated fatty acids. Biochim Biophys Acta, 1965; 98:238-51.

Zheng A, Luo J, Meng K, Li J, Bryden W, Chang W, Zhang S, Wang LX, Liu G, Yao B. Probiotic (Enterococcus faecium) induced responses of the hepatic proteome improves metabolic efficiency of broiler chickens (Gallus gallus). BMC Genomics, 2016; 17:89.

How to cite this article:

Deraz SF, Elkomy AE, Khalil AA. Assessment of probiotic-based diets on growth performance, lipid peroxidation, antioxidant capacity, and cecal microflora in broiler chickens. J Appl Pharm Sci, 2019; 9(S1): 030-039. 